\title{
PERAN KELEMBAGAAN DALAM PENGELOLAAN BERKELANJUTAN DANAU BAKUOK
}

\author{
Afrizal dan Mimin Sundari Nasution \\ FISIP Universitas Riau, Kampus Bina Widya Km. 12,5 Simpang Baru Panam, Pekanbaru 28293
}

\begin{abstract}
Lake Bakuok is a conservation area (Conservat area) and Lake Indigenous or lubuk ban that has cultural-based fishing activities. All activities carried out in Lake Bakuok are controlled by Kenegrian Tambang traditional stakeholders who share the same vision in the conservation and protection of the lake area. On the other hand, ecologically Lake Bakuok is very alarming, with the presence of Palm and Rubber Trees planted alongside the lake, as well as the existence of fish cages. Based on the rules on the ban on Lake Bakuok, not all of the rules are implemented and implemented well, although there are already supervising, there are still violations that occur. The many institutions involved in the development of Lake Bakuok so far are still temporal or temporary, and run individually and have not formed a systematic collaboration. This study aims to see how the role of institutions in the sustainable management of Lake Bakuok. The study uses qualitative research methods that aim to get a holistic (holistic) picture of a phenomenon in Lake Bakuok. The results showed several important items that Ninik Mamak had a significant role in the management of Lake Bakuok in Aur Sati Village, all decisions or rules were made based on the agreement of ninik mamak in Tambang District, both the role of policy makers and other strategic roles.
\end{abstract}

\begin{abstract}
Abstrak: Danau Bakuok merupakan kawasan konservasi (Conservat area) dan Danau Adat atau lubuk larangan yang memiliki kegiatan perikanan yang berbasis budaya. Semua kegiatan yang dilaksanakan di Danau Bakuok ini dikendalikan oleh pemangku adat Kenegrian Tambang dimana memiliki visi yang sama dalam upaya pelestarian dan perlindungan kawasan danau. Di Sisi lain secara ekologis Danau Bakuok ini sangat memprihatinkan, dengan adanya Pohon Sawit dan Karet yang ditanam dipinggir danau, serta adanya keramba Ikan. Berdasarkan aturan tentang larangan di Danau Bakuok tersebut, tidak semua aturan tersebut terjalankan dan terlaksana dengan baik, meskipun sudah ada yang mengawasi, masih ada juga pelanggaran yang terjadi. Banyaknya kelembagaan yang terlibat dalam pengembangan Danau Bakuok selama ini masih bersifat temporal atau sementara, serta berjalan masing-masing dan belum membentuk kolaborasi yang sistematis. Penelitian ini bertujuan untuk melihat bagaimana peran kelembagaan dalam pengelolaan berkelanjutan Danau Bakuok. Penelitian menggunakan metode penelitian kualitatif yang bertujuan untuk mendapatkan gambaran menyeluruh (holistik) dari sebuah fenomena di Danau Bakuok tersebut. Hasil penelitian menunjukkan beberapa item penting bahwa Ninik Mamak mempunyai peran yang cukup besar terhadap pengelolaan Danau Bakuok di Desa Aur Sati, segala keputusan ataupun aturan dibuat berdasarkan kesepakatan ninik mamak yang ada di Kecamatan Tambang, Baik Peran sebagai pengambil kebijakan dan peran strategis lainnya.
\end{abstract}

Kata Kunci: kelembagaan, pembangunan berkelanjutan, pengelolaan

\section{PENDAHULUAN}

Di Provinsi Riau tepatnya di Kapubaten Kampar Kecamatan Tambang di Desa Aur Sati terdapat sebuah danau yang bernama Danau Bakuok. Danau ini merupakan kawasan konservasi (conservat area) dan Danau Adat atau lubuk larangan yang memiliki kegiatan perikanan yang berbasis budaya. Hal ini dapat kita lihat dengan adanya kegiatan mena ngkap ikan dalam bahasa daerah setempat di sebut "mauwo" yang sudah menjadi event pesta rakyat yang diadakan sekali dalam setahun yang dahulunya menangkap ikan diperbolehkan hanya dua bulan sekali. Semua kegiatan yang dilaksanakan di Danau Bakuok ini dikendalikan oleh pemangku adat Kenegrian Tambang dimana memiliki visi yang sama dalam upaya pelestarian dan perlindungan kawasan danau.

Event Ma'awuo yang dilakukan berpotensi merusak wilayah konservasi danau Bakuok, Karena kegiatan yang dilakukan bertentangan dengan tujuan dijadikannnya Danau Bakuok sebagai kawasan konservasi dan lubuk larangan yang harusnya bisa melindungi ikan yang ada di Danau tersebut. Terlihat dari alat tangkap yang digunakan bisa menangkap habitat 
yang ada di dalam danau. Selain itu juga Secara ekologis telah terjadi perubahan fisik dari ekosistem mengalir (dalam bentuk sungai) menjadi ekosistem tergenang (dalam bentuk danau). Secara fisik pun antara sungai dan danau ini telah kehilangan hubungan ekologis, namun hubungan ekologis keduanya dapat terjadi pada musim penghujan dimana air sungai meluap (banjir).

Kedudukan kepala adat dan kepala desa setara dan saling bekerja sama dalam menjaga Danau Bakuok ini. Dalam hal ini, kepala adat dan ninik mamak memiliki peran dalam membuat aturan maupun larangan tentang seputaran danau Bakuok, sedangkan kepala desa memiliki peran untuk mengkoordinasi apapun halhal yang berhubungan dengan kepentingan danau Bakuok.Lalu kepala adat dan kepala desa bersama ninik mamak dan perangkat desa lainnya mengadakan rapat dan di bentuklah suatu kelompok yang bertugas untuk mengelola dan mengawasi danau yang disebut kelompok lubuk larangan, yang terdiri dari dubalang yang berasal dari 10 orang setiap sukunya.Dan yang terakhir masyarakat pun juga memiliki peran dalam pengelolaan danau Bakuok ini, yaitu dengan sama-sama menjaga danau agar danau tetap terjaga dan terhindar dari oknumoknum yang menangkap ikan secara sembarangan.

Peran merupakan aspek yang dinamis dalam kedudukan terhadap sesuatu. Apabila seseorang melakukan hak dan kewajibannya sesuai dengan kedudukannya, maka ia menjalankan suatu peran (Soeharto, 2002). Teori peran (role theory) adalah teori yang merupakan perpaduan teori, orientasi, maupun disiplin ilmu, selain dari psikologi, teori peran berawal dari dan masih tetap digunakan dalam sosiologi dan antropologi (Sarwono, 2002). Dalam ketiga ilmu tersebut, istilah "peran" diambil dari dari dunia teater. Dalam teater, seorang actor harus bermain sebagai seorang tokoh tertentu dan dalam posisinya sebagai tokoh itu ia mengharapkan berperilaku secara tertentu. Dari sudut pandang inilah disusun teori-teori peran. Menurut Biddle dan Thomas (1966) teori peran terbagi menjadi empat golongan yaitu yang menyangkut :

1. Orang-orang yang mengambil bagian dalam interaksi sosial;

2. Perilaku yang muncul dalam interaksi tersebut;

3. Kedudukan orang-orang dalam perilaku;

4. Kaitan antara orang dan perilaku.

Beberapa dimensi peran sebagai berikut:

1. Peran sebagai suatu kebijakan. Penganut paham ini berpendapat bahwa peran merupakan suatu kebijkasanaan yang tepat dan baik untuk dilaksanakan;

2. Peran sebagai strategi. Penganut paham ini mendalilkan bahwa peran merupakan strategi untuk mendapatkan dukungan dari masyarakat (public supports);

3. Peran sebagai alat komunikasi. Peran didayagunakan sebagai instrumen atau alat untuk mendapatkan masukan berupa informasi dalam proses pengambilam keputusan. Persepsi ini dilandaskan oleh suatu pemikiran bahwa pemerintahan dirancang untuk melayani masyarakat, sehingga pandangan dan preferensi dari masyarakat tersebut adalah masukan yang bernilai guna mewujudkan keputusan yang responsif dan responsibel;

4. Peran sebagai alat penyelesaian sengketa, peran didayagunakan sebagai suatu cara untuk mengurangi atau meredam konflik melalui usaha pencapaian konsesus dari pendapat-pendapat yang ada. Asumsi yang melandasi persepsi ini adalah bertukar pikiran dan pandangan dapat meningkatkan pengertian dan toleransi serta mengurangi rasa ketidakpercayaan dan kerancuan;

5. Peran sebagai terapi. Menurut persepsi ini, peran diakukan sebagai upaya masalahmasalah psikologis masyarakat seperti halnya perasaan ketidakberdayaan, tidak percaya diri dan perasaan bahwa diri mereka bukan komponen penting dalam masyarakat (Horoepoetri, Arimbi dan Santosa, 2003),

Keberadaan organisasi saling berkaitan dan berinterkasi dengan teori kelembagaan lokal. Scoot (2008), mengemukakan organisasi diciptakan sebagai mekanisme instrumental untuk mencapai tujuan tertentu untuk sebagian 
variabel dan dari waktu ke waktu diubah menjadi lembaga. Lebih lanjut menurut Selznick dalam (Scoot, 2008) dijelaskan bahwa dampak tujuan dari aksi sosial dalam lingkungan organisasi (struktur berdasarkan tindakan rasional, mekanisme dan alat dalam membuat tujuan yang spesifik, karakteristik sosial anggota di sistem organisasi) merupakan bagian dari peraturan yang telah disepakati, sehingga lingkungan organisasi tersebut ditrasformasikan pada kelembagaan melalui penanaman nilai (infused with value). Proses transformasi nilai organisasi melalui kelembagaan lokal berpengaruh pada karakteristik struktur sehingga memiliki identitas yang berbeda (Scoot, 2008). Dengan demikian, keberadaan organisasi sebagai kendaraan untuk menwujudkan nilai dan tujuan dalam mengembangkan teknologi sedangkan kelembagaan lokal menjadi struktur kekuatan manusia yang berkomitmen terhadap beberapa nilai, dengan menekankan pemeliharaan nilai untuk melindungi kekuatan di masyarakat.

Pendapat Selznick dipengaruhi oleh pendekatan Merton bahwa model dari proses berjalannya kelembagaan lokal berada dalam organisasi birokrasi yang dikendalikan sesuai perintah, sebaliknya Selznick menfokuskan pada proses dalam bagian organisasi yang dikhususkan pada seperangkat nilai yang disepakati karena organisasi adalah (1) sistem sosial; (2) tujuan atau prosedur dan cenderung untuk mencapai status mapan serta; (3) nilai diresapi terlembakan. Sehingga ketiga lingkungan di organisasi tersebut dapat menjadi lembaga melalui proses pelembagaan (institutionalized).

Proses pelembagaan organisasi dilakukan dengan penanaman nilai melalui berbagai persyaratan. Melalui penanaman nilai maka memperoleh identitas struktur karakter yang berbeda dengan lainnya sehingga menyimpan nilai-nilai yang unik. Struktur dan tujuan organisasi yang ditransformasikan ke dalam kelembagaan dengan waktu yang relatif lama akan memunculkan komitmen dari anggota untuk berpatisipasi sehingga memunculkan kekuatan yang mengikat lingkungan dimana organisasi itu berada. Dengan demikian, struktur yang memiliki kekuatan menjadi komitmen nilai yang akan melindungi setiap kegiatan organisasi. Melalui proses kekuatan dalam organisasi akan mengidentifikasi cara memegang kekuasaan dan mampu melestarikan kekuasaan tersebut untuk mengikat anggota dan mencapai tujuan yang di harapkan (Scoot, 2008).

Pengelolaan danau Bakuok dengan pola adat, didukung dengan banyaknya kelembagaan yang terlibat dalam mengelola danau bakuok. Kolaborasi yang berjalan tentu menjadi sistematis yang akan terkolaborasi, ditambah dengan dijadikan wilayah konservasi memungkinkan untuk melakukan kolaborasi yang baik dengan, seluruh stakeholder. Pengembangan dari organisasi yang mengelola yang awalnya sederhana kemudian dapat berkembang. Menurut DeSeve dalam Dewi (2012) menyebutkan ada beberapa item penting yang bisa dijadikan pengukur keberhasilan sebuah network atau kolaborasi dalam governance, meliputi a. Tipe network structured (struktur jaringan). Menjelaskan tentang deskripsi konseptual suatu keterkaitan antara elemen satu dengan elemen lain yang menyatu secara bersamasama yang mencerminkan unsur-unsur fisik dari jaringan yang ditangani.

b. Commitment to a common purpose (komitmen terhadap tujuan). Mengacu pada alasan mengapa sebuah network atau jaringan harus ada.

c. Trust among the participants (kepercayaan di antara para stakeholder). Adanya saling percaya diantara para pelaku/ peserta yang terangkai dalam jaringan didasarkan pada hubungan professional atau sosial.

d. Governance. Termasuk didalamnya adanya saling percaya diantara para pelaku, ada batas-batas siapa yang boleh terlibat dan siapa yang tidak boleh terlibat, dan terdapat aturan main yang jelas yang disepakati bersama, serta kebebasan menentukan bagaimana kolaborasi dijalankan.

e. Access to authority (akses terhadap kekuasaan). Akses terhadap kekuasaan, yakni tersedianya standar-standar ketentuan prosedur-prosedur yang jelas yang diterima 
secara luas.

f. Distributive accountability/responsibility (pembagian akuntabilias/responsibilitas). Berbagi governance (penataan, pengelolaan, manajemen secara bersamasama dengan stakeholder lainnya) dan berbagi sejumlah pembuatan keputusan kepada seluruh anggota jaringan; dengan demikian berbagi tanggung jawab untuk mencapai hasil yang diinginkan.

g. Information sharing (akses informasi para stakeholder) yakni kemudahan akses bagi yang bukan anggota sepanjang bisa diterima oleh semua piha

h. Access to Resource (sumber daya yang tersedia). Ketersediaan sumber keuangan, teknis, manusia dan sumberdaya lainnya yang diperlukan untuk mencapai tujuan network.

Kolaborasi yang dimunculkan dalam pengelolaan danau bakuok, dengan pola berkelanjutan harapan bahwa keberlangsungan dari danau tersebut yang menyentuh aspek ekonomi, lingkungan dan sosial. Melihat begitu pentingnya Danau Bakuok bagi masyarakat dari segi sektor perikanan, ekonomi, budaya maupun sektor lainnya dan untuk melestarikan sumber daya ikan, maka diperlukan tindakan kelembagaan untuk mendukung keanekaragaman ikan dan wilayah konservasi danau.

\section{METODE}

Jenis penelitian model pengembangan kelembagaan danau bakuok berkelanjutan di Kabupaten Kampar ini adalah metode penelitian kualitatif, yang difokuskan di Danau Bakuok Desa Aur Sati Kecamatan Tambang Kabupaten Kampar. Informan penelitian dalam penelitian yaitu:Perangkat Adat (ninik mamak), Kepala Desa, Kepala Dinas Dinas Lingkungan Hidup dan Kehutanan (DLHK) serta beberapa masyarakat Desa. Dengan mengumpulkan data primer dan sekunder melalui Teknik Wawancara, Observasi dan Studi Kepustakaan. Semua hasil data tersebut dikumpulkan dan dipelajari sehingga menjadi suatu kesatuan yang utuh. Kemudian untuk keabsahan hasil penelitian ini, Peneliti menggunakan teknik triangulasi data sehingga kegiatan check, re-check dan cross- check antara materi atau data dengan observasi ini dilakukan crosscheck melalui persepsi penelitian. Aktivitas dalam analisis data kualitatif dilakukan secara interaktif dan berlangsung secara terus menerus sampai tuntas.

\section{HASIL DAN PEMBAHASAN}

Tata kelola Danau Bakuok ini bertujuan untuk melestarikan kearifan lokal yang ada dan menjadikan danau ini sebagai destinasi wisata. Dalam tata kelola danau Bakuok ini melibatkan ninik mamak, pemerintah desa dan masyarakat. Dalam hal ini Ninik mamak memliki peran yang cukup besar dalam pengelolaan danau Bakuok ini, segala aturan dibuat oleh Ninik Mamak. Dalam pengembangan danau bakuok, adapun lembaga yang berperan dapat dilihat pada Tabel 1 Kelembagaan yang ada dalam mengelola danau bakuok, terdiri dari banyak stakeholder, yang memiliki fungsi dan kontribusi masing-masing dalam mengelola danau.

Tabel 1. Kontribusi Kelembagaan dalam Pengembangan Danau Bakuok

\begin{tabular}{|c|c|c|}
\hline No & Kelembagaan & Kontribusi \\
\hline 1 & $\begin{array}{lll}\text { Kementerian } & \text { Perikanan } & \text { dan } \\
\text { Kelautan RI } & & \\
\end{array}$ & $\begin{array}{l}>1000 \text { bibit ikan (ikan patin, ikan } \\
\text { gurami, ikan lomak, ikan motan } \\
\quad(2015) \\
>\quad 30.000 \text { Bibit Ikan Nilem (2018) } \\
>\quad 70.000 \text { Bibit ikan lomak ( 2018) }\end{array}$ \\
\hline 2 & Dinas Perikanan Provinsi Riau & $>1000$ bibit ikan (2016) \\
\hline 3 & Dinas Pariwisata Provinsi Riau & $\begin{array}{l}> \\
\begin{array}{l}\text { Pembangunan Rumah Adat } \\
\text { Sekitar Danau Bakuok }\end{array} \\
>\quad \begin{array}{l}\text { Promosi Melalui Web } \\
\text { Bantuan Baju dan baliho event } \\
\text { mauwuo }\end{array} \\
>\begin{array}{l}\text { Bantuan penari untuk pembukaan } \\
\text { event Ma'awuo }\end{array} \\
>\text { Spanduk }\end{array}$ \\
\hline 4 & Dinas Perikanan Kab. Kampar & $\begin{array}{l}>\quad 50 \text { ton bibit ikan }(2017) \\
\quad 5 \text { buah plakat }(2017) \\
>\quad 1000 \text { bibit ikan }(2018) \\
>\quad 6 \text { buah sampan }(2015)\end{array}$ \\
\hline 5 & Dinas Pariwisata Kab. Kampar & $\begin{array}{llll}\text { Promosi melalui } & \text { Web dan } \\
\text { Medsos }\end{array}$ \\
\hline 6 & LAM Riau & \\
\hline 7 & Desa Aur Sati & $\begin{array}{l}\text { Wilayah } \\
\begin{array}{l}\text { Perencanaan } \\
\text { kegiatan }\end{array}\end{array}$ dan fasilitator \\
\hline 8 & Ninik Mamak & $\begin{array}{l}>\text { Aturan dan hukum adat } \\
>\text { Fasilitasi Musyawarah }\end{array}$ \\
\hline 9 & PTP N V & $\begin{array}{l}\text { Bantuan peminjaman Alat } \\
\text { pemotong rumput setiap bulan } \\
\text { Bantuan pembersih air danau } \\
\text { setahun sekali }\end{array}$ \\
\hline 10 & PT. Hervania & \\
\hline
\end{tabular}

Pada tabel terlihat kontribusi kelembagaan terhadap pengembangan Danau Bakuok, namun kontribusi kelembagaan ini masih bersifat temporal atau sementara dan secara kelembagaan tidak terdokumentasi dengan baik. Di sisi lain secara ekologis Danau Bakuok 
ini sangat memprihatinkan, dengan adanya Pohon Sawit dan Karet yang ditanam dipinggir danau, serta adanya keramba Ikan. Berdasarkan aturan tentang larangan di Danau Bakuok tersebut, tidak semua aturan tersebut terjalankan dan terlaksana dengan baik, meskipun sudah ada yang mengawasi danau masih ada juga pelanggaran yang terjadi. Banyaknya kelembagaan yang terlibat dalam pengembangan danau bakuok selama ini, berjalan masingmasing dan belum membentuk kolaborasi yang sistematis.

Danau Bakuok ini di atur berdasarkan hukum adat, yang mana aturan tentang sekitaran Danau Bakuok di buat langsung oleh kepala adat ataupun ninik mamak setempat yang merupakan bentuk kebijakan dari kepala adat dan ninik mamak di desa tersebut. Di dalam hasil musyawarah Ninik Mamak Kenegerian Tambang-Terantang dibuat lah suatu keputusan dan aturan mengenai larangan di Danau Bakuok. Adapun aturan tersebut sebagai berikut:

1. Ninik Mamak maupun anak kemenakan tidak dibenarkan menanam sawit di seberang pinggir Danau Bakuok.

2. Ninik Mamak maupun anak kemenakan tidak dibenarkan membuat keramba sepanjang perairan Danau Bakuok, bagi yang sudah terlanjur membuat keramba, hanya diberi izin 1 kali panen.

3. Ninik Mamak ataupun anak kemenakan dilarang keras meracun dan menyentrum ikan di sepanjang perairan Danau Bakuok.

Dari hasil wawancara, dapat diketahui bahwa dalam hal pengelolaan Danau Bakuok seluruhnya dilimpahkan kepada pihak desa dan ninik mamak, peran dari Dinas Pariwisata Kabupaten Kampar hanya sebagai yang menjembatani dan mempromosikan setiap kegiatan yang ada di Danau Bakuok seperti acara Maawuo, karena danau hanya dikelola saat ada keperluan dan kepentingan saja seperti pada acara Maawuo.

Selain itu berdasarkan hasil observasi peneliti di lapangan, belum ada aturan yang pasti dan kuat tentang pelanggaran dan sanksi yang diberikan kepada masyarakat apabila melanggar aturan yang ada, sebab masih ditemui masyarakat yang menangkap ikan sembarangan, ditepian danau juga masih banyak ditumbuhi pohon sawit dan keramba-keramba ikan masyarakat yang ada di danau, selain itu permukaan danau juga banyak ditumbuhi semak-semak seperti tidak terawat.

\section{SIMPULAN}

Berdasarkan penelitian dan pembahasan yang telah dilakukan Peneliti di Desa Aur Sati Kecamatan Tambang Kabupaten Kampar, maka dapat ditarik kesimpulan bahwa Ninik Mamak mempunyai peran yang cukup besar terhadap pengelolaan Danau Bakuok di Desa Aur Sati, segala keputusan ataupun aturan dibuat berdasarkan kesepakatan ninik mamak yang ada di Kecamatan Tambang, baik peran sebagai pengambil kebijakan dan peran strategis lainnya.

\section{DAFTAR RUJUKAN}

Alikodra, Hadi S.2012. Konservasi Sumber daya Alam dan Lingkungan. Yogyakarta: Gadjah Mada University Press

Amirullah, dkk. 2003. Perilaku Organisasi. Malang: Bayumedia

Bateman, Thomas S., Snell Scott A. 2008. Manajemen: Kepemimpinan dan Kolaborasi dalam Dunia yang Kompetitif. Jakarta: Salemba Empat

Biddle, B.J dan Thomas, E.J. 1966. Role Theory: Concept and Research. New York: Wiley.

Buwono, Y.R. 2017. Identifikasi dan Kerapatan Ekosistem Danau Bakuok Di Kawasan Teluk Pangpang Kabupaten Banyuwangi. Samakia: Jurnal Ilmu Perikanan, Volume 8,No. 1, April 2017.

Dewi, Ratna Trisuma. 2012."Faktor-Faktor yang Mempengaruhi Collaborative Governance dalam Pengembangan Industri Kecil." Tesis Program Pasca Sarjana Universitas Sebelas Maret Surakarta.

Djamal Irwan. Zoer'aini. 2017. PrinsipPrinsip Ekologi. Jakarta: Bumi Aksara

Gary N. McLean. 2006. Organization Development; Principles - Processes 
- Performance. Barrett Koehler Publishers, Inc. San rancisco.

Ghufron H. Kordi K.M, 2012.Ekosistem Danau Bakuok: Potensi, fungsi dan pengelolaan. Jakarta: Rineka Cipta

Gibson, Ivancevich, Donnelly. 1996. Organisasi; Perilaku, Struktur, Proses. Erlangga, Jakarta.

Gumilar. I. 2012. Partisipasi Masyarakat Pesisir dalam Pengelolaan Ekosistem Hutan Danau Bakuok Berkelanjutan di Kabupaten Indramayu. Jurnal Akuatika, vol. III No. 2 / September 2012 (198211) ISSN 0853-2523

Horoepoetri, Arimbi, Achmad Santosa. 2003. Peran Serta Masyarakat dalam Pengelolaan Lingkungan. Jakarta: Walhi.

Muhtadi Rangkuti, Ahmad dkk. 2017. Ekosistem Pesisir dan Laut Indonesia. Jakarta: Bumi Aksara

Purnobasuki, H. 2005. Tinjauan Perspektif Hutan Danau Bakuok. Airlangga University Press. Surabaya.

Sarwono, S. W. (2002). Psikologi Sosial: Individu dan Teori-teori Psikologi Sosial. Jakarta: PT. Balai Pustaka

Senoaji. G. 2016. Peranan Ekosistem Danau Bakuok di Pesisir Kota Bengkulu dalam Mitigasi Pemanasan Global Melalui Penyimpanan Karbon. Jurnal Manusia dan Lingkungan, Vol. 23, No. 3, September 2016: 327-333

Setyawan AD, Winarno K dan Purin CP. 2003. Ekosisitem Danau Bakuok di Jawa: Restorasi. Jurnal Biodiversitas Vol. 4 (2).

Setyawan. A, dkk. 2006. Pemanfaatan Langsung Ekosistem Danau Bakuok di Jawa Tengah dan Penggunaan Lahan di Sekitarnya; Kerusakan dan Upaya Restorasinya, Jurnal BIODIVERSITAS Vol. 7, No. 3, Juli 2006, hal. 282-291

Sigit, Soehardi. 2003. Perilaku Organisasional. Yogyakarta : BPFE UST

Soeharto I.2002.Studi kelayakan proyek industri. Penerbit Erlangga. Jakarta

Supriharyono. 2007. Konservasi Ekosistem Sumber Daya Hayati di Wilayah Pesisir dan Laut Tropis. Pustaka Pelajar. Yogyakarta.

Totok Mardikanto dan Poerwoko Soebiato. 2015.Pemberdayaan Masyarakat dalam Perspektif Kebijakan Publik. Alfabeta, Bandung.

Wardhani, M.K. 2017. Kawasan Konservasi Danau Bakuok: Suatu Potensi Ekowisata. Jurnal KELAUTAN, Volume 4, No.1 April 2011

William J. Rothwell \& Roland Sullivan.2005. Practicing Organization Development, John Wiley \& Sons, Inc. San francisco. 